\title{
Mesenchymal stromal cells and rheumatic diseases: new tools from pathogenesis to regenerative therapies
}

\author{
PAOLA CIPRIANI ${ }^{1}$, PIERO RUSCITTI ${ }^{1}$, PAOLA DI BENEDETTO ${ }^{1}$, \\ FRANCESCO CARUBBI $^{1}$, VASILIKI LIAKOULI ${ }^{1}$, ONORINA BERARDICURTI ${ }^{1}$, \\ FRANCESCO CICCIA $^{2}$, GIOVANNI TRIOLO ${ }^{2} \&$ ROBERTO GIACOMELLI $^{1}$ \\ ${ }^{1}$ Rheumatology Unit, Clinical Science and Biotechnology Department, University of L'Aquila, L'Aquila, Italy, and \\ ${ }^{2}$ Rheumatology Unit, Internal Medicine Department, University of Palermo, Palermo, Italy
}

\begin{abstract}
In recent years, mesenchymal stromal cells (MSCs) have been largely investigated and tested as a new therapeutic tool for several clinical applications, including the treatment of different rheumatic diseases. MSCs are responsible for the normal turnover and maintenance of adult mesenchymal tissues as the result of their multipotent differentiation abilities and their secretion of a variety of cytokines and growth factors. Although initially derived from bone marrow, MSCs are present in many different tissues such as many peri-articular tissues. MSCs may exert immune-modulatory properties, modulating different immune cells in both in vitro and in vivo models, and they are considered immune-privileged cells. At present, these capacities are considered the most intriguing aspect of their biology, introducing the possibility that these cells may be used as effective therapy in autoimmune diseases. Therefore, stem cell therapies may represent an innovative approach for the treatment of rheumatic diseases, especially for the forms that are not responsive to standard treatments or alternatively still lacking a definite therapy. At present, although the data from scientific literature appear to suggest that such treatments might be more effective whether administered as soon as possible, the use of MSCs in clinical practice is likely to be restricted to patients with a long history of a severe refractory disease. Further results from larger clinical trials are needed to corroborate preclinical findings and human non-controlled studies, and advancement in the knowledge of MSCs might provide information about the therapeutic role of these cells in the treatment of many rheumatic diseases.
\end{abstract}

Key Words: mesenchymal stromal cells, pathogenesis, regenerative therapy, rheumatic disease

\section{Introduction}

In recent years, mesenchymal stromal cells (MSCs) have been largely investigated and tested as a new therapeutic tool for several clinical applications, including the treatment of different rheumatic diseases. MSCs are responsible for the normal turnover and maintenance of adult mesenchymal tissues as the result of their multipotent differentiation abilities and their secretion of a variety of cytokines and growth factors. MSCs are defined according to the criteria proposed by the International Society for Cellular Therapy: (i) MSCs must be plastic-adherent in standard culture conditions; (ii) They must express CD105, CD73 and CD90 but lacking in the expression of CD45, CD34, CD14 or CD11b, CD79 $\alpha$, CD19 and the major histocompatibility complex (MHC) class II cell surface receptor, HLA-DR; (iii) They must be able to differentiate toward osteoblasts, adipocytes and chondroblasts in vitro [1]. Besides these three lineages, according to environmental factors such as growth factors, hypoxia and the extracellular three-dimensional environment, MSCs may differentiate into other different cell types [2]. Although initially derived from bone marrow (BM), where they reside in a perivascular location and express markers specific for pericytes [2], MSCs are present in many different tissues. In fact, MSCs may be isolated from many peri-articular tissues including synovium, synovial fluid, cartilage, intra-articular fat and periosteum. Adipose tissue is a major source of adipose derived stromal cells (ADSCs) [3]. ADSCs are mainly located in the stroma, and only few of them display a perivascular location. Their transcriptomic and proteomic profiles show some specificities linked to their tissue origin, reflecting the influence of the microenvironment. Of note, ADSCs show angiogenic

Correspondence: Paola Cipriani, MD, Rheumatology Unit, Clinical Science and Biotechnology Department, University of L'Aquila, 67100 L'Aquila, Italy.

E-mail: paola.cipriani@cc.univaq.it 


\section{P. Cipriani et al.}

potential through trans-differentiation toward the endothelial phenotype; they control the evolution of scars through their antifibrotic effects and protect against apoptosis $[4,5]$.

MSCs may exert immune-modulatory properties, modulating different immune cells in both in vitro and in vivo models [3-5], through both cell contact-dependent mechanisms and soluble factors $[6,7]$, mainly resulting in the generation of cells with regulatory activity [8-10]. MSCs are considered immune-privileged cells: they express low levels of cell-surface HLA class I molecules, whereas HLA class II, CD40, CD80 and CD86 are not detectable on the cell surface, and this phenotype might allow escape to the immune surveillance [11]. Although many rheumatic diseases, and mainly the autoimmune diseases, reflect a pathological activation of the immune system and activation of the inflammatory cascade, the potential role of an altered microenvironment may be considered, including a disturbance of resident MSCs. Several results, available in literature, suggest that despite some functional defects of resident MSCs, they may continue to exert immune modulatory effects and many functional defects may be reverted in vitro, suggesting a potential role of autologous MSC transplantation in autoimmune diseases. On the other hand, their immune privilege offers the possibility of easier allogeneic transplantation, overcoming the self-recognition barrier. Thus, at present, both the possibilities-autologous and allogeneic transplantation-may be considered, and the results of future clinical trials will suggest the best choice for any different rheumatic disease. However, it must be pointed out that both their immunologically privileged phenotype and immunosuppressive skills may be considered the most intriguing aspects of their biology, which suggests that these cells may be used as effective therapy in autoimmune diseases $[3,6,10,12-14]$.

In this review, we report the results available in the literature concerning the therapeutic role of MSCs in rheumatic diseases.

\section{Osteoarthritis}

Chronic disability in people over 50 years of age is strongly associated with disorders of the musculoskeletal system, and osteoarthritis (OA) involving the spine and diarthrodial joints is the most common condition. All joints can be affected by OA, but the hand, knee and hip represent the main targets of the disease [15]. OA has an enormous social and economic burden, increasing in parallel with population age [16]. Moreover, OA is associated not only with disability but also with other conditions, such as obesity, neuropathic pain, trauma, depression and sleep disorders, and may be an important cause of premature death $[17,18]$.

\section{Pathogenesis}

$\mathrm{OA}$ is a complex condition characterized by degeneration of the articular cartilage, which is accompanied by damage of the underlying bone, sub-chondral bone sclerosis, development of cysts and osteophytes and synovial inflammation. Destruction of articular cartilage stimulates synovial lining cells and articular chondrocytes to synthesize and secrete proteolytic enzymes: matrix metalloproteinase, aggrecanase, proinflammatory cytokines and soluble mediators such as nitric oxide and prostaglandins, which degrade the cartilaginous matrix and accelerate articular cartilage degradation [19-21]. OA has been considered a noninflammatory condition for some time; however, increasing evidence supports that inflammation is present in the synovial tissue of OA, raising the hypothesis that synovitis and the immune system could be active players in OA development and progression [22]. Synovial inflammation occurs in the majority of OA patients and is a predictive factor for disease progression [23-25].

Current treatments produce symptomatic rather than regenerative results and include pain control (steroidal and non-steroidal anti-inflammatory drugs), viscosupplementation (injections of sodium hyaluronate) and a variety of nutraceuticals (chondroitin sulphate, glucosamine, omega-3 fatty acids). None of these compounds has a useful impact on the progressive loss of joint tissues [26]. Joint-resident MSCs in humans were first described in synovial membrane [27], but it is well known that MSCs, or cells with properties very similar to MSCs, can be detected in different tissues of diarthrodial joints, such as the synovial fluid compartment, the synovial fat pad, the articular cartilage surface zone, ligaments and the meniscus [28-31]. These cells share the same surface markers and functions of BM-derived MSCs. However, minor phenotypic differences between different populations of joint-resident MSCs may reflect their specific tissue of origin or, alternatively, the influence of culture conditions used for their isolation [32].

The widespread distribution of MSCs in diarthrodial joints is associated with key functional characteristics that contribute to the maintenance of healthy tissues and/or their ability to respond to injury. These cells provide a reservoir of repairing cells that are activated in response to growth, remodeling or repair. Furthermore, they might act as immune system sentinels to reduce inflammation or modulating T-cell activation $[25,27]$.

Several reports suggest that MSCs are depleted in the marrow of patients with advanced $\mathrm{OA}$ and that 
their growth factor receptor profile is altered because higher concentrations of growth factors are required to support their proliferation and differentiation. Murphy et al. [33] demonstrated that MSCs obtained from BM during joint replacement surgery in patients with end-stage OA were functionally deficient in terms of in vitro proliferation and differentiation. These functional deficiencies can be reversed by supplementation of the culture medium enriched by epidermal growth factor or fibroblast growth factor 2 [34,35]. Indeed, inclusion of fibroblast growth factor 2 in the culture medium promoted proliferation and inhibited senescence through the phosphatidylinositol 3-kinase-AKT and E3 ubiquitin-protein ligase $\mathrm{Mdm} 2$ pathways, respectively [36].

Other studies have suggested that the role of aging influences MSC phenotype. In particular, human periosteal MSCs from younger donors exhibit spontaneous chondrogenic activity in culture, whereas such activity is absent in cells from older donors [37]. Moreover, MSCs isolated from trabecular bone samples from OA patients showed an in vitro aging-related loss of proliferation when compared with that in healthy donors [38].

As far as the pathogenetic role of MSCs or MSClike progenitor cells in $\mathrm{OA}$ is concerned, it must be pointed out that a large number of Notch-1-positive cells are found in articular cartilage from patients with OA when compared with normal control subjects, mainly located in clusters of proliferating cells [39]. The presence of Notch-1 expression has been associated with MSC-like cells and progenitor populations in normal cartilage [30]. On this basis, chondrocyte clusters, a hallmark feature of OA articular cartilage, might be considered the result not only of the de-differentiation and subsequent proliferation of resident chondrocytes but also related to the migration of progenitor cells [40].

The interplay between transforming growth factor (TGF)- $\beta, \mathrm{A}$-disintegrin and metalloproteinase with thrombospondin motifs 5 (ADAMTS5) and cartilageresident and/or bone-resident MSCs in OA may be involved in the inappropriate cartilage repair response. ADAMTS5 is the main aggrecanase involved in degradation of mouse cartilage [41], and studies concerning Adamts5-/- mice with experimental OA showed that the lack of this metalloproteinase activity resulted in a decrease of joint fibrosis and evidence of cartilage erosions $[42,43]$. Furthermore, in the presence of ADAMTS5, TGF- $\beta$ is a fibrosis inducer, through TGF- $\beta$ receptor type 1 (also known as Alk5) and subsequent phosphorylation of Smad2 and Smad3. On the contrary, lacking ADAMTS5, TGF- $\beta$ is an inducer of chondrogenesis through serine/ threonine-protein kinase receptor R3 (also known as
Alk1) and subsequent phosphorylation of Smad1, Smad5 and Smad9 [44].

\section{Preclinical results}

Because of the ability of MSCs to synthesize cartilage and bone, thus enhancing joint repair and reducing the degenerative changes, it is appealing to suggest that the replacement of defective populations by MSC transplant may represent an attractive therapeutic option (Figure 1).

The effectiveness of intra-articular delivery of autologous MSCs has been tested in a variety of preclinical animal models of surgically induced OA, post-traumatic $\mathrm{OA}$, collagenase-induced $\mathrm{OA}$ and spontaneous OA [45]. MSCs were seeded into threedimensional biodegradable scaffolds before implantation into cartilage. Direct intra-articular injection might be possible in early stages of the disease when the defect is restricted to the cartilage layer, whereas a scaffold would be required to support the MSCs in the case of sub-chondral bone defect exposed over large areas [46]. Treatment of post-traumatic OA in goats through direct intra-articular delivery of a suspension of goat MSCs elicited a meniscal repair response, resulting in a significant improvement in cell-treated joints when compared with controls, with evidence of cartilage protection. Of note, newly regenerated meniscal tissue consisted of host cells associated with small numbers of transplanted cells, which suggests that transplanted MSCs act as building blocks for the formation of repair tissue and influence the behavior of resident cells [47].

MSCs have been previously embedded into different scaffolds for attachment and growth and then implanted into cartilage defect by means of open arthrotomy. These scaffolds include a synthetic or natural extracellular matrix consisting of hyaluronic acid and gelatin, bioceramic scaffold- $\beta$-tricalcium phosphate, fibrin glue, polylactic acid, hyaluronic gel sponge and collagen gel [48]. In this setting, a bio-scaffold coated with TGF$\beta 3$ for surgical replacement of the synovial joint in rabbits led to the formation of a useful and structurally similar articular cartilage layer, with restoration of function through the recruitment of endogenous MSCs [49].

To avoid the risks of arthrotomy, the possibility of the use of direct intra-articular injection of MSCs suspended in hyaluronic acid for cartilage repair has also been explored in different animal models of OA. In these studies, autologous BM-derived MSCs combined with a hyaluronan solution were injected into the injured joints intra-articularly. Marked improvement in cartilage healing and regeneration, reduced osteophyte formation and sub-chondral sclerosis were observed in 


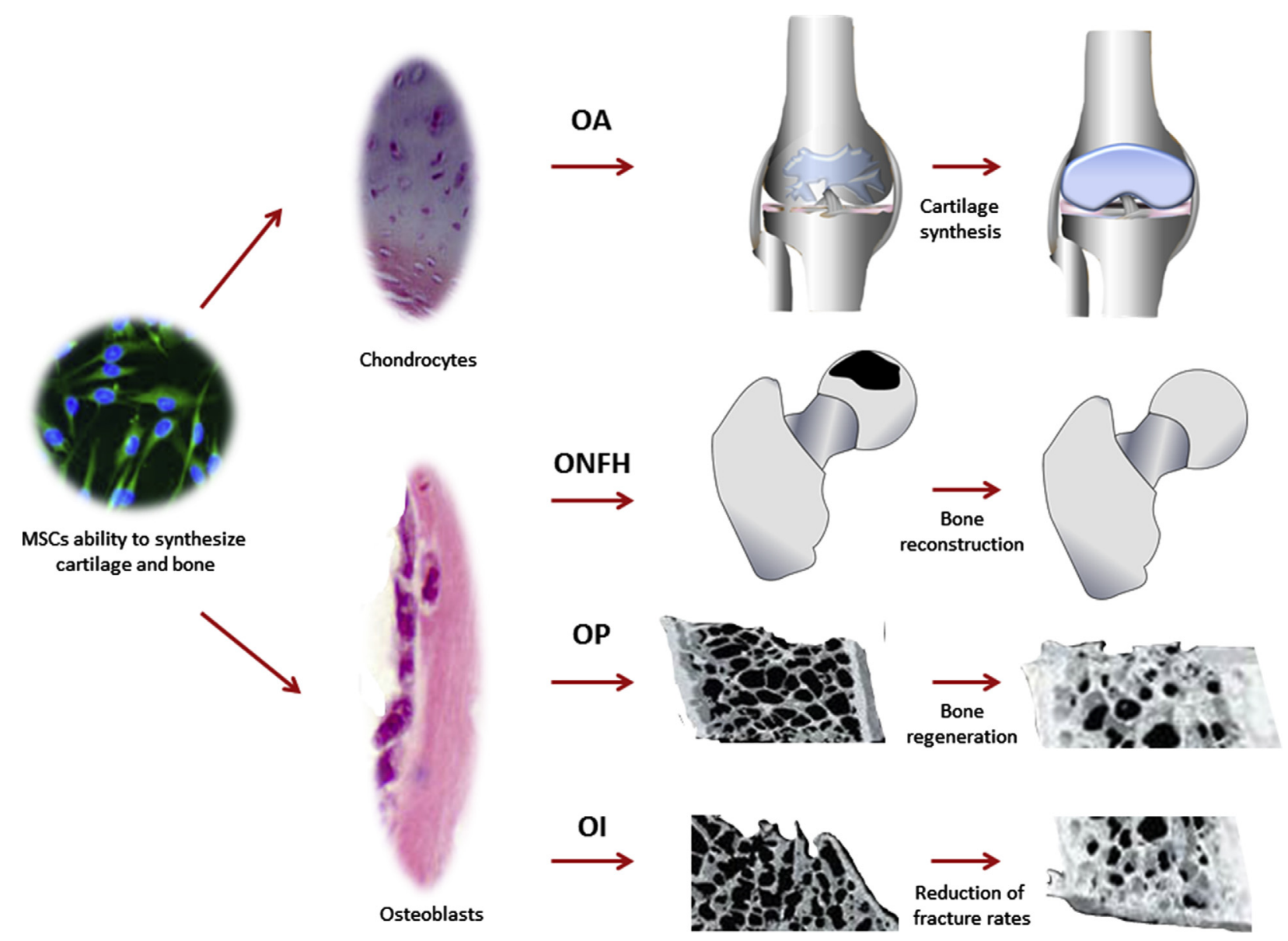

Figure 1. The replacement of defective populations by MSCs transplant may represent an attractive therapeutic option for bone and cartilage diseases. MSCs are able to induce cartilage synthesis during OA. When transplanted, the same cells, proliferate and differentiate to osteoblasts in the bone, thus ameliorating OI, ONFH and OP.

MSC-treated joints in comparison with hyaluronan- or saline-treated controls [48].

In collagenase-induced and surgery-induced models of OA mice treated with kartogenin, which improves matrix structure and weight-bearing ability, chondrogenic activation of resident progenitor cells in the cartilage increased [50]. Kartogenin binds the FC-1 fragment of filamin-A, disrupting its association with core-binding factor $\beta$-subunit $(\mathrm{CBF} \beta)$, part of a heterodimeric transcription factor complex. Increased nuclear availability of $\operatorname{CBF} \beta$ leads to activation of runt-related transcription factor 1 (RUNX1) and its associated network of genes, which are important in chondrogenesis and tissue repair $[51,52]$.

At present, MSCs have been mainly obtained from $\mathrm{BM}$ through the use of a highly invasive procedure; however, ADSCs show similar characteristics when compared with BM-derived MSCs and provide an abundant and easily accessible cell source for cartilage repair. In fact, in dogs with chronic osteoarthritis of the coxofemoral and humeroradial joints, a clinically significant improvement was observed in ADSC-treated joints when compared with controls $[53,54]$.

Human umbilical cord-derived MSCs (UCMSCs), isolated from extra-embryonic tissue (Wharton's jelly) after birth, are a promising candidate source of MSCs with several advantages: abundant supply, painless collection, no donor site morbidity and faster and longer self-renewal ability in vitro [55]. When compared with BM-derived MSCs and under specific conditions, UC-MSCs are able to produce more glycosaminoglycans, aggregans and type I collagen and show enhanced cell attachment, cell proliferation and chondrogenesis $[56,57]$.

\section{Clinical therapy}

Preclinical observations provided the rationale to pursue MSC therapeutic application in vivo in OA. Wakitani et al. [58] performed the first clinical study on 24 patients with $\mathrm{OA}$ who underwent a tibial osteotomy. Autologus BM-derived MSCs, embedded in collagen gel, were transplanted into the articular cartilage defect and covered with 
autologous periosteum. Forty-two weeks after transplantation, the defects were covered with white soft tissue, and hyaline cartilage-like tissue was partially observed. The arthroscopic and histological grading score significantly improved in the celltransplanted group when compared with the cellfree control group [58]. To avoid invasive surgery, percutaneous injection of MSCs was used in a small cohort of patients with knee osteoarthritis. The autologous MSCs derived from adipose tissue of abdominal origin, combined with hyaluronic acid, platelet-rich plasma, calcium chloride and a nanogram dose of dexamethasone, were injected. At week 12, patient pain improved more than $90 \%$; the range of motion also improved, and magnetic resonance imaging showed a significant increase in the thickness of meniscus cartilage on the knees [59].

Presently, several clinical trials are currently ongoing, and the majority of these studies use autologous, culture-expanded MSCs from BM or adipose tissue, and, in a few cases, allogeneic MSCs, derived from $\mathrm{BM}$ or cord blood. In the majority of cases, intra-articular administration of MSCs is carried out directly to the synovial fluid compartment, and the scaffold is replaced with a vehicle, mostly hyaluronic acid, which represents a normal component of extracellular matrix and is currently used for therapeutic purposes in OA. Although the majority of ongoing trials tested a cell injection dose of $1-4 \times$ $10^{7}$ cells in a single injection, dose-finding studies are required to identify the optimal cell dose leading to the best outcome [25].

\section{Rheumatoid arthritis}

Rheumatoid arthritis (RA) is a common autoimmune disease that is associated with progressive disability, systemic complications, early death and socioeconomic costs. The cause of RA is unknown. However, advances in understanding the pathogenesis of the disease have fostered the development of new therapeutics, with improved outcomes. The current treatment strategy is to initiate aggressive therapy soon after diagnosis and to escalate the therapy, guided by an assessment of disease activity, in pursuit of clinical remission [60].

\section{Pathogenesis}

Recently, published data reported that BM-derived MSCs from RA patients showed chondrogenic potential that was similar to that observed in MSCs isolated from healthy control subjects [61]. In this study, marrow samples were collected during bone surgery and adherent cell cultures were established from patients with RA, patients with osteoarthritis and healthy control subjects. The authors documented that culture-expanded MSCs from RA and OA patients did not differ significantly from the normal population with respect to their chondrogenic potential in vitro. The ability of total protein and proteoglycan synthesis and collagen II messenger RNA expression by cell aggregates was similar for all cell preparations in the presence of the appropriate growth and differentiation factors. However, synovial membrane-derived MSCs from patients with active RA were spontaneously defective, in terms of their clonogenicity and chondrogenic differentiation potential, in the absence of appropriate stimuli. In fact, a negative relationship among synovial MSCs and chondrogenic and clonogenic capacities, on the one hand, and the magnitude of inflammatory synovitis in RA patients, on the other hand, was reported in RA patients [62].

The possible role of MSCs in the immunopathology of RA has been suggested by MarinovaMutafchieva et al. [63]. The authors aimed to determine the involvement of MSCs in the induction of collagen-induced arthritis (CIA). An analysis of the joints at day 10 after immunization with type II collagen in adjuvant versus adjuvant alone revealed synovial hyperplasia without leukocytic infiltration. Large, round cells expressing bone morphogenetic protein receptors (BMPRs), which serve as markers for primitive MSCs, were present in increased numbers in the $\mathrm{BM}$ adjacent to the joint, in the synovium, and within the enlarged bone canals connecting BM to the synovium. Similar changes were observed in mice receiving adjuvant without collagen. Adjuvant-induced infiltration of BMPR + cells and enlargement of bone canals were abrogated by anti-tumor necrosis factor- $\alpha$ (anti-TNF- $\alpha$ ) treatment and were absent in TNFR p55/p75(-/-) mice. Increased numbers of BM cells and enlarged bone canals were observed in nonimmunized TNF- $\alpha$ transgenic mice (which spontaneously develop arthritis). Therefore, it has been postulated that BM-derived stromal cells might migrate to the joint space before the onset of acute inflammation in the TNF- $\alpha$ transgenic mouse model. In these animals, anti-TNF- $\alpha$ therapy inhibits local migration of BM stromal cells and prevents the clinical signs of arthritis [63].

It has been further hypothesized that RA synoviocytes might be transformed into BM-derived MSCs stuck at early stages of differentiation by pro-inflammatory factors. This evidence suggested that the abnormal phenotype of RA fibroblast-like synoviocytes might derive from an aberrant activation of mechanisms that normally serve to provide physiological repair of joint tissues. Arthritogenic stimuli provide aberrant production of damage signals that cause sustained influx of BM-derived MSCs 
to the joint. Thus, the RA fibroblast-like synoviocytes appear as a heterogeneous population of underdifferentiated MSCs, arrested at intermediate stages of differentiation by the inflammatory milieu [64].

\section{Preclinical results}

Studies of MSCs as cellular therapy for CIA reported conflicting results. The first study that used MSCs, administered intravenously in mice, showed that there was no benefit of cellular therapy for the reduction of CIA [65]. On the contrary, another study showed that a single intraperitoneal (IP) injection of allogeneic MSCs in mice prevented the development of severe arthritis. MSCs did not localize to the joints, which suggests that the clinical improvement was not due to their ability to repair the joints but probably by reducing the levels of proinflammatory cytokines, such as IL-10, and de novo generation of T-regulatory (Treg) cells [66].

Further positive results from MSC therapy were reported after daily IP injection of human or murine allogeneic and syngeneic adipose ADSCs. After the onset of the disease, 5 days of treatment significantly reduced the incidence and severity of arthritis in the CIA model. Conversely, intra-articular injection of ADSCs was less effective than was the IP route. In this context, after collecting cells from lymph nodes of MSC-treated mice, a significant decrease of Th1 cytokines and Th17 cytokine was observed, whereas the levels of the regulatory cytokines such as IL-10 were increased $[67,68]$.

Other studies, however, failed to demonstrate any improvement in experimental CIA with MSC treatment. One study showed that MSCs exacerbated the arthritis in mice by promoting the secretion of IL-6 and IL-17 [69]. Schurgers et al. [70] were unable to demonstrate any benefit from MSC therapy in CIA [70]. In contrast, injection of Treg cells before or after disease onset led to a dramatic improvement in arthritis. One study examined the effect of human allogeneic ADSCs on collagen-reactive T cells isolated from patients with RA in vitro [71]. These cells inhibited both the proliferation and the expression of pro-inflammatory cytokines by collagen-activated $\mathrm{T}$ cells, whereas an increased number of IL10-producing $\mathrm{T}$ cells was reported. Furthermore, these cells impaired the production of the matrixdegrading enzymes collagenase and gelatinase, which are involved in the inflammatory response. In addition, results from recent studies further support the potential of MSCs in the treatment of autoimmune inflammatory arthritis; in fact, immune modulation and reduction of articular damage after treatment with MSCs were observed [71]. These findings suggest that MSC therapy may be able to reset the immune system by reducing the deleterious Th1/Th17 response and enhancing the protective Treg cell response.

\section{Clinical therapy}

These above-mentioned experiences suggest that MSCs might exert a profound inhibitory effect on the proliferation, invasive behavior and inflammatory responses of synoviocytes, suppress T-cell activation and induce the generation of Tregs. Furthermore, cell-based therapy with the use of human MSCs significantly ameliorated CIA in mice. These data suggest that MSCs might open new therapeutic perspectives in RA as observed in other rheumatic diseases (Table I). Future studies must clarify whether the in vitro ability of MSCs to generate de novo Treg cells might be considered a safer and helpful therapeutic option when compared with neutralizing antibodies against single-cytokine signaling [72-74]. At present, many clinical trials are ongoing (http://www. clinicaltrials.gov/), aiming to evaluate safety and efficacy of MSC treatment in RA patients.

\section{Systemic lupus erythematosus}

Systemic lupus erythematosus (SLE) is a chronic autoimmune disease that involves multiple organs including renal, cardiovascular, neural, musculoskeletal and cutaneous systems with a remarkable variability in clinical presentation. The pathogenesis of SLE is a complex interplay of genetic, endogenous and environmental stimuli, resulting in a breakdown of selftolerance and development of autoimmunity with organ damage. Major organ manifestations, particularly central nervous system and renal disease, have long been identified as markers of poor prognosis $[75,76]$.

Although the most widely and classically used immunosuppressive therapies led to a significant improvement in survival over recent years, these treatments often result in serious side effects such as infection, ovarian failure and secondary malignancy, and the disease often relapses after drug withdrawal $[77,78]$.

\section{Pathogenesis}

In recent years, impaired capacities of proliferation, differentiation, secretion of cytokines and immune modulation of BM-derived MSCs from patients with SLE were reported [79]. BM-derived MSCs from SLE patients may be successfully culture-expanded, but these cells grew more slowly than did those of normal control subjects. Several abnormalities of cytoskeleton were found that might explain the decreased cell expansion in vitro, which are probably related to different gene expressions of cytoskeleton 
Table I. Main results of available literature concerning the therapeutic role of MSCs in rheumatic diseases.

\begin{tabular}{|c|c|c|c|c|}
\hline $\begin{array}{l}\text { Disease } \\
\text { [Reference] }\end{array}$ & MSCs type & Route of administration & Patients & Outcome \\
\hline OA $[41]$ & Autologous BM-derived MSCs & Injected in to involved joint & 24 & $\begin{array}{l}\text { Improvement of clinical, } \\
\text { arthroscopic and histological } \\
\text { grading scores }\end{array}$ \\
\hline OA [42] & $\begin{array}{l}\text { Autologous adipose tissue-derived } \\
\text { MSCs }\end{array}$ & Injected into involved joint & 4 & $\begin{array}{l}\text { Improvement of clinical and } \\
\text { magnetic resonance data }\end{array}$ \\
\hline SLE [77] & $\begin{array}{l}\text { Allogeneic BM- or UC-derived } \\
\text { MSCs }\end{array}$ & Systemic administration & 87 & $\begin{array}{l}\text { Improvement of disease activity } \\
\text { and serologic feature }\end{array}$ \\
\hline SLE [78] & Autologous BM-derived MSCs & Systemic administration & 2 & $\begin{array}{l}\text { No change in disease activity } \\
\text { indexes }\end{array}$ \\
\hline SSc $[88]$ & $\begin{array}{l}\text { Allogeneic haploidentical-related } \\
\text { donor MSCs }\end{array}$ & Systemic administration & 5 & $\begin{array}{l}\text { Improvement of skin score and } \\
\text { acral necrosis }\end{array}$ \\
\hline SSc [89] & $\begin{array}{l}\text { Autologous adipose tissue-derived } \\
\text { MSCs }\end{array}$ & Systemic administration & 6 & Improvement of skin score \\
\hline OI [96] & $\begin{array}{l}\text { Allogeneic haploidentical-related } \\
\text { donor MSCs }\end{array}$ & Systemic administration & 3 & $\begin{array}{l}\text { Increase of dense bone formation } \\
\text { and body mineral content }\end{array}$ \\
\hline OI [98] & $\begin{array}{l}\text { Allogeneic HLA-mismatched male } \\
\text { fetal MSCs }\end{array}$ & $\begin{array}{l}\text { In utero at } 32 \text { nd week of } \\
\text { gestation }\end{array}$ & 1 & $\begin{array}{l}\text { During the first } 2 \text { years of life, } 3 \\
\text { fractures were noted }\end{array}$ \\
\hline ONFH [113] & Autologous BM-derived MSCs & Implantation in femoral head & 19 & $\begin{array}{l}\text { Reduction of pain and joint } \\
\text { symptoms }\end{array}$ \\
\hline ONFH [114] & Autologous BM-derived MSCs & Implantation in femoral head & 100 & $\begin{array}{l}\text { Improvement of clinical conditions } \\
\text { and decrease of necrotic area }\end{array}$ \\
\hline
\end{tabular}

components of BM-derived MSCs in these patients $[80,81]$. Despite this finding, MSCs from SLE have a normal karyotype: these cells express CD29, CD44 and CD105 and lack CD14, CD34, CD45 and HLA-DR. Furthermore, these MSCs were defective in secreting cytokines such as TGF- $\beta$, and a downregulation of IL-6 and IL-7 messenger RNA expression was reported [80].

Some authors recently showed that expression of the p16 cyclin-dependent kinase inhibitor 4A ( $p 16-$ $I N K 4 A$ ) gene was significantly increased, whereas the levels of CDK4, CDK6 and $\mathrm{p}-\mathrm{Rb}$ expression were decreased in the MSCs from SLE patients. Furthermore, they showed that p16INK4A might be the major factor involved in the cellular senescence process of MSCs from SLE patients by regulating cytokine secretion and the ERK1/2 signaling pathway. This evidence might explain why MSCs from SLE patients displayed prominent senescent characteristics [82]. In fact, these cells were found to be larger and flattened in appearance, with a slower growth rate, compared with fibroblast-like MSCs from normal control subjects. Telomerase activity was upregulated in the MSCs of SLE patients, paralleling the disease activity, and these cells showed early signs of senescence, which might be a contributory factor to disease pathogenesis [83].

Of note, in bone marrow aspirates from SLE patients, an increased apoptosis of MSCs, a downregulation of $\mathrm{Bcl}-2$ and an upregulation of cytochrome C were observed [84]. In addition, intracellular reactive oxygen species (ROS), which appears to be the main cause of the senescence of human MSCs [85,86], were higher in SLE BM-derived MSCs compared with those of normal control subjects. It has been suggested that the increased phosphorylation of Fox3, observed in SLE MSCs, impairing the activation of FoxO3, results in the cytoplasmic sequestration and inhibition of its downstream transcriptional activity, with production of high levels of ROS, thus favoring senescence. However, it is still unknown whether this defect of BMderived MSCs is primary or secondary. It is well known that an increase in serum levels of IL-6, IL-10 and $\mathrm{TNF} \alpha$ is present during the disease and closely correlates with SLE disease activity; specific receptors for these cytokines are expressed by stem cells, and the signaling mediated by these receptors may lead to an alteration of MSC proliferation [87-90]. Therefore, during SLE, some biological condition might impair the functional integrity of stem cells, and further studies must completely elucidate the role of these cells in the complex pathogenetic scenario of the disease.

\section{Preclinical results}

Therapies with autologous or allogeneic MSCs have been tested in several SLE murine models (Figure 2). Recently, in MRL/lpr mice, a disease improvement was shown, in a dose-dependent manner, after the injection of human MSCs from healthy donors [91]. After transplantation with allogeneic MSCs, a reduction of serum levels of anti-double-stranded DNA (anti-dsDNA) antibodies and 24 hours of proteinuria in the same mice strain 


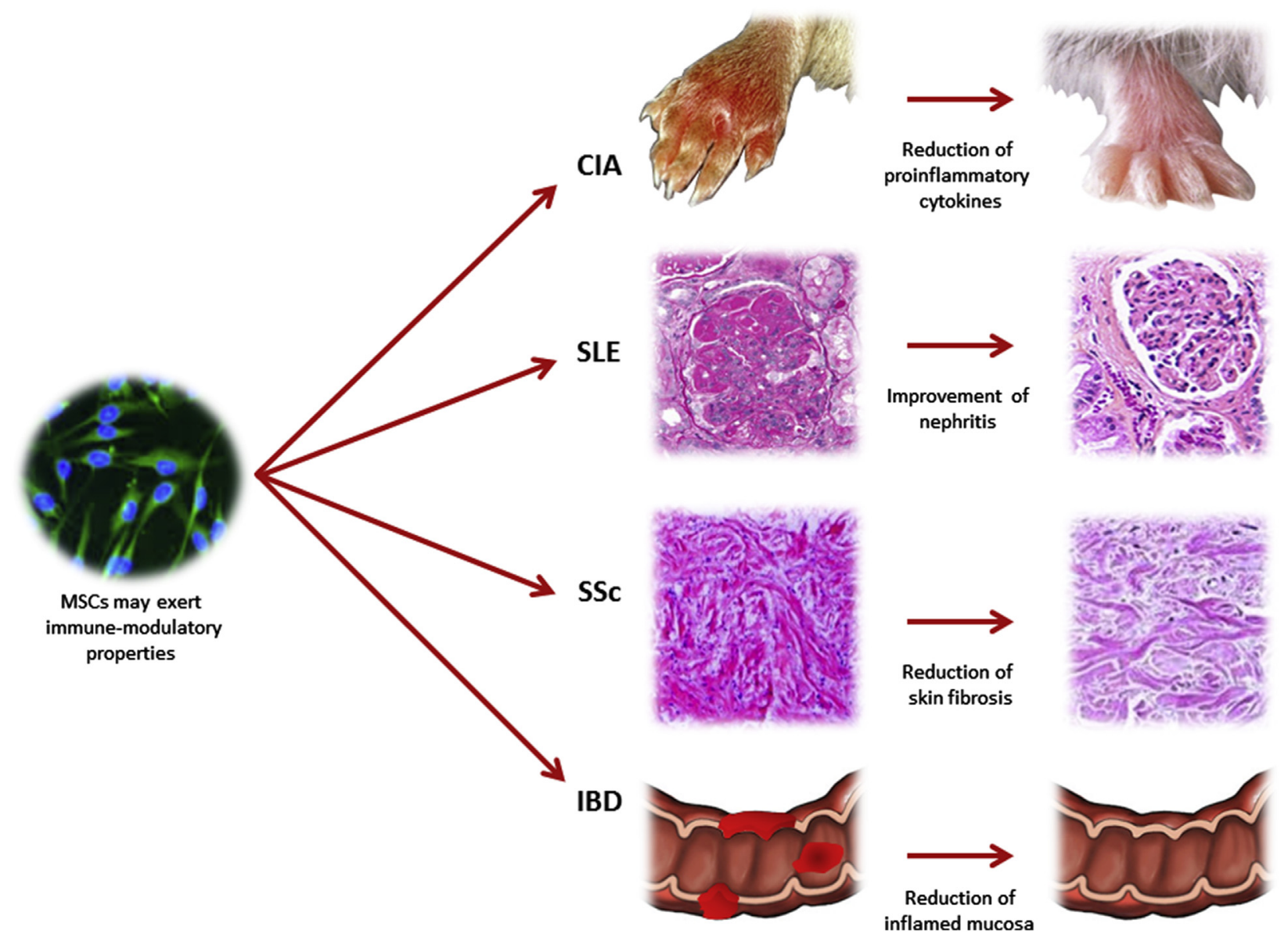

Figure 2. MSCs might exert a profound inhibitory effect on the inflammatory responses, significantly ameliorating CIA in mice. In addition, MSCs therapy showed an improvement of nephritis during SLE, reduction of skin fibrosis during SSc and reduction of inflamed mucosa during inflammatory bowel diseases (IBD).

were found. In addition, an increase the Th1 cell subset and a decrease of the $\mathrm{Th} 2$ cell subset were found. Histopathological examination pointed out a significant decrease of the renal injury in MSCtreated mice with a significant reduction of $\mathrm{C} 3$ deposition in renal tissue and improvement of glomerulosclerosis [91].

More recently, it has been shown that MSC transplantation resulted in a significant reduction in serum levels of anti-dsDNA, reduction of glomerular immunoglobulin $G$ deposition and restoration of glomerular structure, which suggests that MSCs might be an effective therapeutic option for an MRL/lpr lupus murine model [92].

Choi et al. [93] investigated the effects of longterm serial human ADSC transplantation on SLE in NZB/WF1 mice. A higher survival rate, with improvement of histological and serological abnormalities associated with a decreased incidence of proteinuria, was observed. In addition, a restoration of $\mathrm{CD} 4+/ \mathrm{FoxP} 3+$ cells and cytokine production were reported in transplanted NZB/WF1 mice [93].
Despite these recent basic studies that have clearly pointed out the potential of the use of MSCs to treat SLE, the mechanisms by which MSCs exert their immunomodulatory and reparative effects are still largely unknown. It might be linked to multiple mechanisms mediated by both soluble factors and cell contact. In addition, it is possible that interactions between immune cells and MSCs in the tissue microenvironment might modulate MSC function and contribute to the outcome of MSCbased therapy [79].

\section{Clinical therapy}

Supported by the clinical benefits of MSCs therapy in SLE mice, Wang et al. [94] carried out a study to assess the safety and efficacy of allogeneic MSC transplant in patients with refractory SLE. Eighty-seven patients with persistently active SLE, refractory to standard treatments or affected by a life-threatening visceral involvement, were enrolled and successfully transplanted with allogeneic BM-derived or umbilical 
cord-derived MSCs [95]. within contrast to previous findings of Carrion et al. [96], disease activity decreased, as revealed by significant changes in SLE disease activity score and levels of serum autoantibodies, albumin and complement factors. Of note, in this context, no difference in disease remission was observed between patients with or without cyclophosphamide therapy pretreatment after 4 years of follow-up, which strongly suggests that the reported clinical benefits were not related to cytotoxic therapy [95].

Although controlled, randomized studies must understand the real place of this treatment in the therapy of human SLE, these results suggest that allogeneic MSC therapies are a safe procedure that shows the ability to induce a good clinical response in refractory SLE.

\section{Systemic sclerosis}

Systemic sclerosis (SSc) is an autoimmune disease in which vascular alterations, extensive fibrosis and autoantibodies against various cellular antigens are the main clinical and pathogenetic features. SSc can lead to severe dysfunction and failure of almost any internal organ. The involvement of visceral organs is a major factor in determining the prognosis [97].

\section{Pathogenesis}

BM-derived MSCs from patients with SSc appeared to be similar to those from healthy donors in their phenotype and capacity to differentiate into adipogenic and osteogenic lineages. Larghero et al. [98] assessed BM-derived MSC function and phenotype in 12 patients with SSc and compared them with 13 healthy normal control subjects. The parameters included (i) the number of colony-forming unit fibroblasts; (ii) the ability to differentiate along the adipogenic and osteogenic lineages; (iii) the expression of specific cell surface antigens, which can define the MSCs population; (iv) the ability to support normal hematopoiesis associated with the suppression of in vitro lymphocyte proliferation. The results showed that SSc MSCs displayed the same phenotype and functional activities of healthy donor MSCs [98].

However, our previous work provided evidence that these cells showed both an impairment to acquire the functions of mature endothelium when induced to differentiate toward endothelial cells [99] and an early senescence, as demonstrated by a reduced telomerase activity $[99,100]$.

Recent findings showed similarities between pericytes and BM-derived MSCs. Because of difficulties in pericyte isolation, in a previous work, we explored the possibility of the use of BM-derived MSCs as a pericyte surrogate, trying to clarify their role in supporting neo-angiogenesis during SSc. Both SSc and healthy control BM-derived MSCs were treated with TGF- $\beta$ and prostaglandin-derived growth factor-BB to normally differentiate toward pericytes. We showed that BM-derived MSCs isolated from SSc patients displayed an upregulation of pericyte-specific markers and a reduced proliferative activity. With the use of a co-culture assay, in a tridimensional scaffold of both BM-derived MSCs and microvascular endothelial cells (MVECs), we observed that SSc BM-derived MSCs improve endothelial cell tube formation in specific stressed conditions, such as a sub-optimal number of cultured endothelial cells, thus behaving as pericytes. They display a more mature and myofibroblast-like phenotype, probably related to microenvironmental cues operating during the disease. After their coculture with healthy control MVECs, SSc BMderived MSCs underwent a phenotypic modulation that re-programs these cells toward pro-angiogenic behavior [101].

Recently, Guiducci et al. [102] tried to characterize BM-derived MSCs from SSc patients for the expression of factors implicated in three different functions: MSC recruitment at sites of injury, angiogenesis and fibrosis. The study also analyzed whether the production/release of bioactive mediators by MSCs were affected by cytokines that are generally found upregulated in SSc serum and tissues and whether these MSCs may modulate dermal MVECs. In SSc MSCs, the basal expression of proangiogenic factors was significantly increased compared with that in healthy control MSCs. SSc MSC-conditioned medium showed a greater proangiogenic effect on MVEC than did healthy control MSCs. According to the authors, SSc MSCs appear to constitutively over-express and release bioactive mediators/pro-angiogenic factors, possibly supporting dermal MVEC angiogenesis [102].

Although several lines of evidence are present in published literature on the role of MSCs in the pathogenesis of SSc, conflicting and not fully elucidated data are still available.

\section{Clinical therapy}

Although senescent, SSc MSCs maintain considerable immunosuppressive properties and a normal ability to generate functional Tregs. Therefore, senescence does not represent a limitation for their potential use, both in cellular and regenerative medicine, to target SSc. In fact, BM-derived MSCs might therefore be considered in an autologous setting for therapeutic use in SSc [103]. 
There are only a few case reports and small case series available in literature about the use of MSCs to treat SSc patients. The first case report published in literature showed that the infusion of MSCs from a haploidentical allogeneic cell donor induced a marked improvement in the modified Rodnan skin thickness score in a patient with diffuse SSc, without internal organ involvement [104]. Subsequently, a 34-year-old woman with SSc who had acute gangrene of the upper and lower limbs was treated with intravenous expanded autologous MSCs. Areas of necrotic skin were reduced after the first MSCs, and, after the third infusion, angiography showed revascularization of the patient's extremities [105]. More recently, allogeneic MSC transplantation was performed in five white patients with diffuse SSc. All patients tolerated MSC transplantation without immediate toxicity. Four of the five patients showed improvement in the modified Rodnan skin score. Acral necrosis improved, or healed, in all the affected patients [106]. Furthermore, positive results have been reported after the transplantation of autologous ADSCs in hyaluronic acid solution in six SSc patients. The authors showed a significant improvement in tightening of the skin without complications such as anechoic areas, fat necrosis or infections, thus suggesting that ADSCs are a potentially valuable source of cells for therapy [107].

Although the use of MSCs in patients with SSc is limited, another stem cell type is currently being assessed as therapy for severe SSc. Since 2001, the efficacy, safety and long-term effects of autologous hematopoietic stem cell transplantation in SSc have been studied in one phase II and two phase III randomized, controlled trials in Europe and North America [108]. However, caution should be applied before considering the positive improvement of MSC transplantation, and further controlled studies must be planned in this area to establish safety, efficacy and selection of appropriate patients.

\section{Osteogenesis imperfecta}

Osteogenesis imperfecta (OI), or brittle-bone disease, is a genetic disease that is linked to dominant mutations in the type I collagen genes, COL1A1 and $C O L 1 A 2$, and is characterized by osteopenia and multiple fractures, severe bony deformities and considerably shortened stature. Two categories, structural defects and quantitative defects, have been reported $[109,110]$.

\section{Preclinical results}

A murine model showed preclinical data that transplantation of MSCs should attenuate, or even correct, genetic disorders of bone or cartilage. MSCs obtained from wild-type mice were infused into a mouse model of OI. The results showed that up to $12 \%$ of the donor cells were found in various tissues, including bones. This finding suggested that MSCs were able to home to the bones, differentiating into osteocytes and producing of normal collagen type I with possible partial restoration of the OI phenotype [111]. Intrauterine transplantation of human fetal MSCs in OI mice showed that MSCs were able to decrease fracture rates and skeletal abnormalities, thus correcting bone defects [112]. The marked reduction of fracture rates and skeletal abnormalities might suggest a scientific basis for MSCs in the pathogenesis and future treatment of OI.

\section{Clinical therapy}

Actually, only MSC-based cell and gene therapies have shown positive effects in OI [113]. Horwitz et al. [114] in 1999 transplanted allogeneic bone marrow from HLA-identical or single-antigen-mismatched siblings into three children with OI. Three months after engraftment, all patients showed positive results [114]. Subsequently, isolated, purified and expanded allogeneic MSCs, successively engrafted into six children, were reported as feasible therapy for OI. In fact, formation of new dense bone, increase in bone mineral content and reduction in bone fracture frequencies were observed [115]. More recently, a novel clinical therapeutic option was published in literature: MSC transplantation in uterus. In a female fetus with severe OI, allogeneic MSCs from an HLA-mismatched male fetal liver of a 10-week aborted fetus were injected. The cells were cultured and injected into the umbilical vein at the 32nd week of gestation. At 9 months of age after delivery, analysis of the donor cells revealed $0.3 \%$ of the donor cells. The follow-up revealed only three fractures during the first 2 years, normal psychomotor development and correct growth tendency [116]. With the development of gene therapy, MSCs have been explored as a potential carrier for different genes in OI treatment. Millington-Ward et al. [117] developed a mutation-independent short interfering RNA, targeting a common intragenic a single nuclear protein in the COL1A1 gene, and the protein levels of $C O L 1 A 1$ were suppressed by up to $85 \%$. Therefore, a good therapeutic effect might be achieved through silencing the mutant allele and then replacing the mutated gene with normal allele [117].

\section{Osteonecrosis of the femoral head}

Osteonecrosis of the femoral head (ONFH), or avascular necrosis of the femoral head, is a progressive 
degenerative disease that results from interruption of blood supply to the bone and may lead to the total collapse of femoral head. It is a painful disorder that commonly affects 30- to 50-year-old individuals. ONFH is a multifactorial disease, and the pathogenesis is still unknown. Late consequences of ONFH include femoral head collapse and subsequent degeneration of the hip joint $[118,119]$.

\section{Preclinical results}

Various preclinical investigations showed in different animal models the therapeutic effectiveness of MSCs on ONFH. These data pointed out that transplanted autologous or allogeneic MSCs were capable of survival, proliferation and differentiation into osteoblasts directly in the necrotic femoral head after transplantation [120-123]. Furthermore, improvement in necrosis repair and enhancement of bone regeneration were reported. In addition, intravenously implanted MSCs displayed good results by migration and reparation of the injured tissues. Furthermore, it has been recently reported that the implanted MSCs not only proliferate and differentiate into osteoblasts but also secrete angiogenic cytokines [124,125].

MSCs transduced with different viral vectors carrying various genes have been explored to estimate the potential effect of treatment on ONFH. The enhancement of blood vessel regeneration, tissue reparation and bone reconstruction in the $\mathrm{ONFH}$ rabbit model was reported after transplantation of hepatocyte growth factor-transgenic BM-derived MSCs. Furthermore, the change in hepatocyte growth factor concentration promoted MSCmediated osteogenic regeneration by increasing osteogenic differentiation and proliferation of MSCs $[126,127]$.

\section{Clinical therapy}

Autologous bone marrow grafts have been used for the treatment for ONFH since 1991 [128], with good results obtained $[129,130]$, and these results have been confirmed by long-term follow-up studies [131].

Zhao et al. [132] evaluated 100 patients with early-stage $\mathrm{ONFH}$ who were recruited and randomly assigned to BM-derived MSC treatment or core decompression treatment. The follow-up results at different times after operations showed that the BM-derived MSCs group had significantly improved clinical conditions, relieved pain and decreased necrotic area in femoral head. No complication was observed, pointing out that autologous BM-derived MSC intervention is a safe and effective treatment for ONFH [132].
Recently, positive results of short-term regeneration of medullar bone-like tissue and long-term reduction in hip pain after treatment of ADSCs in patients with ONFH was reported. The authors suggested that ADSC implantation might be a promising minimally invasive therapy for $\mathrm{ONFH}$ [133].

Although these data showed encouraging and safe interventions in $\mathrm{ONFH}$ in delaying or avoiding femoral head collapse, which may necessitate total hip replacement, further experience and research are needed.

\section{Osteoporosis}

Osteoporosis (OP) is a common disease characterized by a systemic impairment of bone, including mass, strength and microarchitecture, which increases the propensity of fragility fractures. The socioeconomic burden is relevant: approximately $40 \%$ of white postmenopausal women are affected by $\mathrm{OP}$, and their lifetime risk of fracture is until up $40 \%$. From a patient's perspective, fractures, most commonly occurring in the spine, hip or wrist, and the subsequent loss of mobility often induce an important decrease in the quality of life. Bone loss occurs insidiously and is initially asymptomatic; therefore, OP is often only diagnosed after that the first clinical fracture has occurred. Consequently, the aim of therapy should be prevention of bone loss with a consequent reduction of fractures [48].

\section{Pathogenesis}

MSCs have a direct role in the maintenance of bone balance and regeneration. They act through their self-renewal and differentiating properties toward an osteogenic lineage as a source of progenitors for osteoblasts, which are responsible for the anabolic function of the homeostatic balance, and as regulators for osteoclastogenesis. MSC differentiation toward a specific lineage is dependent on hormonal and local factors, which may activate specific transcription factors. Any change in the pathways involved in the differentiative process or in the functional features of MSCs might have important implications during aging and in some osteogenic disorders such as post-menopausal OP [134].

Several authors studied growth, proliferation, differentiation toward osteogenic potential, gene expression and control of the microenvironment of MSCs in OP patients, but the pathogenetic mechanisms are still not fully elucidated and conflicting data are reported $[48,134,135]$.

Some evidence reported that in the BM microenvironment, adipose tissue volume increased from 


\section{P. Cipriani et al.}

$15 \%$ to $60 \%$ between 20 and 65 years of age; furthermore, trabecular bone volume decreased from $26 \%$ to $16 \%$, and these data are probably related to an upregulation of pro-adipogenic and antiosteogenic signaling pathways that commit MSCs toward adipocytes instead of osteoblasts. In addition, it is well known that the number of MSCs committed to the adipocytic lineage increased, whereas the number of those committed to the osteoblastic lineage decreased [136].

Recently, some authors studied the osteogenic differentiation process in MSCs obtained from the peripheral blood of OP patients and normal donors. The results showed that circulating MSCs were increased in OP patients compared with that in healthy control subjects. However, gene expression analysis revealed a downregulation of transcription factors essential for osteoblastic differentiation, such as RUNX-2, $\mathrm{Sp} 7$ and the bone-related genes COL1A1, SPARC and SPP1 in OP patients. Furthermore, lower levels of osteoprotegerin (OPG) and receptor activator of nuclear factor-rB ligand (RANKL) were reported. OPG acts as an inhibitor of osteoclastogenesis, and the lower OPG/RANKL ratio observed in OP patients might reflect a decreased ability of osteoblasts to prevent osteoclast activation. These authors suggested that an impaired osteoblast differentiation might be associated with adipogenic differentiation [135].

On the other hand, previous experience did not support these findings, reporting no difference among the number of osteoprogenitor cells, proliferative potential and osteogenic commitment, differentiation responses to stimulation by $\mathrm{GH}$ and calcitriol [137].

Leptin is a paracrine-signaling molecule that modulates the differentiation of stromal cells toward osteoblasts. It inhibits cell differentiation to adipocytes, and a functional leptin receptor has been found in precursor cells of the osteoblasts lineage. It has been reported that leptin significantly inhibited MSC differentiation toward normal adipocytes but not in OP cells, exerting a low stimulatory osteogenic effect; this impaired leptin action might be due to a decreased leptin production by MSCs and/or a reduced receptor-binding capacity. In addition, normal MSCs display lower levels of peroxisome proliferator-activated receptor- $\gamma$ protein that exerts a protective effect on adipogenesis than the levels observed in OP cells [138].

The effects of other factors contained in the sera of OP patients were studied in postmenopausal OP women, showing that OP MSCs, after stimulation, may preferentially follow an adipocyte differentiation route. Among them, estrogen inhibited osteoclastic bone resorption, thus reducing the frequency of bone remodeling cycles; other factors, such as lipoprotein lipase and glyceraldehyde 3-phosphate dehydrogenase, were able to induce the differentiation of MSC adipocytes, lowering the number of osteoblasts. Bone mass and fat mass are closely regulated during aging and OP [134-138].

\section{Preclinical data}

In 1994, Bruder et al. [139] proposed that the systemic administration of culture-expanded autologous human MSCs might be used to treat OP. They proposed that local bone defects might be repaired through site-directed delivery of MSCs in an appropriate carrier vehicle [139].

On these bases, in several animal models it has been shown that transplantation of autologous or allogeneic MSCs may be able to strengthen the osteoporotic bone in MSC-transplanted animals. In addition, MSCs showed a specific homing to the surface of trabecular bone after directed injection of these cells by intravenous transplantation $[140,141]$.

The bone volume decrease associated with OP is generally accompanied by an increased marrow adipose tissue formation. In this regard, inhibition of adipogenesis and an increase in osteoblastogenesis might provide a novel therapeutic approach for osteopenic disorders. Nuttall et al. [142] reported that cells cultured from human trabecular bone are not only osteogenic, but these cells are able to undergo adipocyte differentiation under defined culture conditions; they induced osteoblast differentiation by 1,25-dihydroxyvitamin D3 and adipocyte differentiation by dexamethasone plus 3-isobutyl1-methylxanthine (IBMX) treatment. Adipogenesis and osteoblastogenesis were characterized by lineage-specific enzyme and gene activities. The results of this study provided evidence for a common pluripotent MSC that is able to undergo either adipogenesis or osteoblastogenesis. Adipogenesis can be induced by long-chain fatty acids and/or the thiazolidinedione troglitazone. Furthermore, the adipogenesis induced by dexamethasone associated with IBMX can be inhibited by IL- $1 \beta$, TNF- $\alpha$ and TGF$\beta$. Therefore, the authors concluded that the specific inhibition of marrow adipogenesis and promotion of osteoblastogenesis of a common precursor cell might suggest a novel therapeutic approach to the treatment of osteopenic disorders [142].

Human bone morphogenetic protein (BMP)-2, BMP-4, BMP-6 and BMP-7 are involved the pathophysiological pathways of osteoporosis. Moreover, BMP-2 plays a prominent role in osteo-induction: it is able to increase both the number of MSCs and the osteogenic activity by enhancement of proliferation and reduction of apoptosis. Preliminary results about 
BMP-2 genetically engineered MSCs, transplanted in OP mouse and sheep models, showed that these cells were able to increase both bone regeneration and fracture healing [143].

RANKL and receptor activator of nuclear factor$\mathrm{rB}$ (RANK) was reported to play an important role in OP MSCs. RANK-Fc is a recombinant protein of the extracellular domain of RANK fused to the Fc region of human immunoglobulin $\mathrm{G}$ and targets as a soluble antagonist against RANKL. Addition of RANK-Fc in an in vitro model reduced the formation of osteoclasts [144].

The interaction among stromal cell-derived factor-1 and CXC chemokine receptor-4 (CXCR4) is a well-known regulator of cell trafficking and homing in bone. Transplantation of MSCs overexpressing CXCR4 alone or co-expressing CXCR4+ RANK-Fc or CXCR4+ cbfa-1 displayed significant protection against ovariectomy induced bone loss. Notably, co-expression groups of CXCR4 + RANKFc or CXCR4 + cbfa-1 indicated more effective results [145].

\section{Clinical data}

More recently, human ADSCs were isolated from patients affected by osteoporotic fractures. ADSCs and BM-derived MSCs of the same donor were harvested and divided into two age groups. The first group included 14 young patients and the other group included 8 elderly patients with osteoporotic fractures. The authors showed that the doubling time of ADSCs from both age groups was maintained below 70 hours, whereas that of BM-derived MSCs increased significantly with the number of passages. When ADSCs and BM-derived MSCs from the same patient were compared, there was a significant increase in the doubling time of BM-derived MSCs in each individual from passages. As far as the osteogenic induction is concerned, the level of matrix mineralization by ADSCs from a group of elderly patients was comparable to that of ADSCs from group of young patients. However, BM-derived MSCs from a group of elderly patients produced the least amount of mineral deposits and had a lower expression level of osteogenic genes. The $p 21$ gene expression and senescence-associated $\beta$-galactosidase activity were lower in ADSCs compared with that in BM-derived MSCs, which might partially be responsible for the greater proliferation and differentiative rate of ADSCs, and suggests a potentially effective role for ADSCs in cell-based regenerative therapy in elderly OP patients [146].

In conclusion, although MSCs demonstrated a promising prospect of clinical application in OP, until now, no report on clinical application of MSCs in OP patients has been published, and further clinical studies must investigate their potential efficacy and safety.

\section{Conclusions}

Stem cell therapies represent an innovative approach for the treatment of rheumatic diseases, especially for forms that are not responsive to standard treatments or alternatively still lacking a definite therapy. At present, although the data from scientific literature seem to suggest that such treatments might be more effective whether administered as soon as possible, the use of MSCs in clinical practice is likely to be restricted to patients with a long history of a severe refractory disease $[147,148]$. Further results from larger clinical trials are needed to corroborate preclinical findings and human non-controlled studies. On these bases, the source of MSCs, the prognostic importance of donor-and-host HLA matching and the optimal administration regime must be further explored. Although no direct MSCrelated adverse effects have been reported, long-term follow-up for patients receiving MSCs are needed. Further advancement in the knowledge of MSCs might provide information about the therapeutic role of these cells in the treatment of many rheumatic diseases.

\section{Acknowledgments}

This work was supported by FIRA (Fondazione Italiana Ricerca per l'Artrite) 2009. The authors thank Mrs Federica Sensini for technical assistance.

Disclosure of interests: The authors have no commercial, proprietary, or financial interest in the products or companies described in this article.

\section{References}

[1] Dominici M, Le Blanc K, Mueller I, Slaper-Cortenbach I, Marini F, Krause D, et al. Minimal criteria for defining multipotent mesenchymal stromal cells. The International Society for Cellular Therapy position statement. Cytotherapy 2006;8:315-7.

[2] Djouad F, Bouffi C, Ghannam S, Noël D, Jorgensen C. Mesenchymal stem cells: innovative therapeutic tools for rheumatic diseases. Nat Rev Rheumatol 2009;5:392-9.

[3] Rehman J, Traktuev D, Li J, Merfeld-Clauss S, TemmGrove CJ, Bovenkerk JE, et al. Secretion of angiogenic and antiapoptotic factors by human adipose stromal cells. Circulation 2004;109:1292-8.

[4] Bartholomew A, Sturgeon C, Siatskas M, Ferrer K, McIntosh K, Patil S, et al. Mesenchymal stem cells suppress lymphocyte proliferation in vitro and prolong skin graft survival in vivo. Exp Hematol 2002;30:42-8. 


\section{P. Cipriani et al.}

[5] Ben-Ami E, Berrih-Aknin S, Miller A. Mesenchymal stem cells as an immunomodulatory therapeutic strategy for autoimmune diseases. Autoimmun Rev 2011;10:410-5.

[6] Cipriani P, Carubbi F, Liakouli V, Marrelli A, Perricone C, Perricone R, et al. Stem cells in autoimmune diseases: Implications for pathogenesis and future trends in therapy. Autoimmun Rev 2013;12:709-16.

[7] Bocelli-Tyndall C, Bracci L, Spagnoli G, Braccini A, Bouchenaki M, Ceredig R, et al. Bone marrow mesenchymal stromal cells (BM-MSCs) from healthy donors and auto-immune disease patients reduce the proliferation of autologous- and allogeneic-stimulated lymphocytes in vitro. Rheumatology (Oxford) 2007;46:403-8.

[8] Krampera M, Glennie S, Dyson J, Scott D, Laylor R, Simpson E, et al. Bone marrow mesenchymal stem cells inhibit the response of naive and memory antigen-specific $\mathrm{T}$ cells to their cognate peptide. Blood 2003;101:3722-9.

[9] Dominici M, Paolucci P, Conte P, Horwitz EM. Heterogeneity of multipotent mesenchymal stromal cells: from stromal cells to stem cells and vice versa. Transplantation 2009;87(9 Suppl):S36-42.

[10] van Laar JM, Tyndall A. Adult stem cells in the treatment of autoimmune diseases. Rheumatology (Oxford) 2006;45: 1187-93.

[11] Di Nicola M, Carlo-Stella C, Magni M, Milanesi M, Longoni PD, Matteucci P, et al. Human bone marrow stromal cells suppress T-lymphocyte proliferation induced by cellular or nonspecific mitogenic stimuli. Blood 2002;99: 3838-43.

[12] Zappia E, Casazza S, Pedemonte E, Benvenuto F, Bonanni I, Gerdoni E, et al. Mesenchymal stem cells ameliorate experimental autoimmune encephalomyelitis inducing T-cell anergy. Blood 2005;106:1755-61.

[13] Rafei M, Campeau PM, Aguilar-Mahecha A, Buchanan M, Williams P, Birman E, et al. Mesenchymal stromal cells ameliorate experimental autoimmune encephalomyelitis by inhibiting CD4 Th17 T cells in a CC chemokine ligand 2dependent manner. J Immunol 2009;182:5994-6002.

[14] Constantin G, Marconi S, Rossi B, Angiari S, Calderan L, Anghileri E, et al. Adipose-derived mesenchymal stem cells ameliorate chronic experimental autoimmune encephalomyelitis. Stem Cells 2009;27:2624-35.

[15] Buckwalter JA, Martin JA. Osteoarthritis. Adv Drug Deliv Rev 2006;58:150-67.

[16] Lawrence RC, Felson DT, Helmick CG, Arnold LM, Choi H, Deyo RA, et al. Estimates of the prevalence of arthritis and other rheumatic conditions in the United States. Part II.Arthritis Rheum 2008;58:26-35.

[17] Gore M, Tai KS, Sadosky A, Leslie D, Stacey BR. Clinical comorbidities, treatment patterns, and direct medical costs of patients with osteoarthritis in usual care: a retrospective claims database analysis. J Med Econ 2011;14:497-507.

[18] McKenna MT, Michaud CM, Murray CJ, Marks JS. Assessing the burden of disease in the United States using disabilityadjusted life years. Am J Prev Med 2005;28:415-23.

[19] Guilak F. Biomechanical factors in osteoarthritis. Best Pract Res Clin Rheumatol 2011;25:815-23.

[20] Goldring MB, Goldring SR. Articular cartilage and subchondral bone in the pathogenesis of osteoarthritis. Ann N Y Acad Sci 2010;1192:230-7.

[21] Stone AV, Loeser RF, Vanderman KS, Long DL, Clark SC, Ferguson CM. Pro-inflammatory stimulation of meniscus cells increases production of matrix metalloproteinases and additional catabolic factors involved in osteoarthritis pathogenesis. Osteoarthritis Cartilage 2014;22:264-74.

[22] de Lange-Brokaar BJ, Ioan-Facsinay A, van Osch GJ, Zuurmond AM, Schoones J, Toes RE, et al. Synovial inflammation, immune cells and their cytokines in osteoarthritis: a review. Osteoarthritis Cartilage 2012;20: 1484-99.

[23] Ayral X, Pickering EH, Woodworth TG, Mackillop N, Dougados M. Synovitis: a potential predictive factor of structural progression of medial tibiofemoral knee osteoarthritis - results of a 1 year longitudinal arthroscopic study in 422 patients. Osteoarthritis Cartilage 2005;13:361-7.

[24] Benito MJ, Veale DJ, FitzGerald O, van den Berg WB, Bresnihan B. Synovial tissue inflammation in early and late osteoarthritis. Ann Rheum Dis 2005;64:1263-7.

[25] Barry F, Murphy M. Mesenchymal stem cells in joint disease and repair. Nat Rev Rheumatol 2013;9:584-94.

[26] Jevsevar DS. Treatment of osteoarthritis of the knee: evidence-based guideline, $2^{\text {nd }}$ edition. J Am Acad Orthop Surg 2013;21:571-6.

[27] De Bari C, Dell'Accio F, Tylzanowski P, Luyten FP. Multipotent mesenchymal stem cells from adult human synovial membrane. Arthritis Rheum 2001;44:1928-42.

[28] Jones EA, Crawford A, English A, Henshaw K, Mundy J, Corscadden D, et al. Synovial fluid mesenchymal stem cells in health and early osteoarthritis: detection and functional evaluation at the single-cell level. Arthritis Rheum 2008;58: $1731-40$

[29] Khan WS, Adesida AB, Tew SR, Longo UG, Hardingham TE. Fat pad-derived mesenchymal stem cells as a potential source for cell-based adipose tissue repair strategies. Cell Prolif 2012;45:111-20.

[30] Dowthwaite GP, Bishop JC, Redman SN, Khan IM, Rooney P, Evans DJ, et al. The surface of articular cartilage contains a progenitor cell population. J Cell Sci 2004;117: 889-97.

[31] Huang TF, Chen YT, Yang TH, Chen LL, Chiou SH, Tsai $\mathrm{TH}$, et al. Isolation and characterization of mesenchymal stromal cells from human anterior cruciate ligament. Cytotherapy 2008;10:806-14.

[32] Segawa Y, Muneta T, Makino H, Nimura A, Mochizuki T, Ju YJ, et al. Mesenchymal stem cells derived from synovium, meniscus, anterior cruciate ligament, and articular chondrocytes share similar gene expression profiles. J Orthop Res 2009;27:435-41.

[33] Murphy JM, Dixon K, Beck S, Fabian D, Feldman A, Barry F. Reduced chondrogenic and adipogenic activity of mesenchymal stem cells from patients with advanced osteoarthritis. Arthritis Rheum 2002;46:704-13.

[34] Scharstuhl A, Schewe B, Benz K, Gaissmaier C, Bühring HJ, Stoop R. Chondrogenic potential of human adult mesenchymal stem cells is independent of age or osteoarthritis etiology. Stem Cells 2007;25:3244-51.

[35] Im GI, Jung NH, Tae SK. Chondrogenic differentiation of mesenchymal stem cells isolated from patients in late adulthood: the optimal conditions of growth factors. Tissue Eng 2006;12:527-36.

[36] Coutu DL, François M, Galipeau J. Inhibition of cellular senescence by developmentally regulated FGF receptors in mesenchymal stem cells. Blood 2011;117:6801-12.

[37] De Bari C, Dell'Accio F, Luyten FP. Human periosteumderived cells maintain phenotypic stability and chondrogenic potential throughout expansion regardless of donor age. Arthritis Rheum 2001;44:85-95.

[38] Jones E, English A, Churchman SM, Kouroupis D, Boxall SA, Kinsey S, et al. Large-scale extraction and characterization of CD271+ multipotential stromal cells from trabecular bone in health and osteoarthritis: implications for bone regeneration strategies based on uncultured or minimally cultured multipotential stromal cells. Arthritis Rheum 2010;62:1944-54. 
[39] Hiraoka K, Grogan S, Olee T, Lotz M. Mesenchymal progenitor cells in adult human articular cartilage. Biorheology 2006;43:447-54.

[40] Koelling S, Kruegel J, Irmer M, Path JR, Sadowski B, Miro X, et al. Migratory chondrogenic progenitor cells from repair tissue during the later stages of human osteoarthritis. Cell Stem Cell 2009;4:324-35.

[41] Stanton H, Rogerson FM, East CJ, Golub SB, Lawlor KE, Meeker CT, et al. ADAMTS5 is the major aggrecanase in mouse cartilage in vivo and in vitro. Nature 2005;434: $648-52$.

[42] Glasson SS, Askew R, Sheppard B, Carito B, Blanchet T, Ma HL, et al. Deletion of active ADAMTS5 prevents cartilage degradation in a murine model of osteoarthritis. Nature 2005;434:644-8.

[43] Wang VM, Bell RM, Thakore R, Eyre DR, Galante JO, Li J, et al. Murine tendon function is adversely affected by aggrecan accumulation due to the knockout of ADAMTS5. J Orthop Res 2012;30:620-6.

[44] Velasco J, Li J, DiPietro L, Stepp MA, Sandy JD, Plaas A. Adamts5 deletion blocks murine dermal repair through CD44-mediated aggrecan accumulation and modulation of transforming growth factor $\beta 1$ (TGF $\beta 1$ ) signaling. J Biol Chem 2011;286:26016-27.

[45] Ameye LG, Young MF. Animal models of osteoarthritis: lessons learned while seeking the "Holy Grail". Curr Opin Rheumatol 2006;18:537-47.

[46] Nöth U, Steinert AF, Tuan RS. Technology insight: adult mesenchymal stem cells for osteoarthritis therapy. Nat Clin Pract Rheumatol 2008;4:371-80.

[47] Murphy JM, Fink DJ, Hunziker EB, Barry FP. Stem cell therapy in a caprine model of osteoarthritis. Arthritis Rheum 2003;48:3464-74.

[48] Liu Y, Wu J, Zhu Y, Han J. Therapeutic application of mesenchymal stem cells in bone and joint diseases. Clin Exp Med 2014;14:13-24.

[49] Lee CH, Cook JL, Mendelson A, Moioli EK, Yao H, Mao JJ. Regeneration of the articular surface of the rabbit synovial joint by cell homing: a proof of concept study. Lancet 2010;376:440-8.

[50] Johnson K, Zhu S, Tremblay MS, Payette JN, Wang J, Bouchez LC, et al. A stem cell-based approach to cartilage repair. Science 2012;336:717-21.

[51] Wang Y, Belflower RM, Dong YF, Schwarz EM, O'Keefe RJ, Drissi H. Runx1/AML1/Cbfa2 mediates onset of mesenchymal cell differentiation toward chondrogenesis. J Bone Miner Res 2005;20:1624-36.

[52] Wotton S, Terry A, Kilbey A, Jenkins A, Herzyk P, Cameron E, et al. Gene array analysis reveals a common Runx transcriptional programme controlling cell adhesion and survival. Oncogene 2008;27:5856-66.

[53] Black LL, Gaynor J, Gahring D, Adams C, Aron D, Harman S, et al. Effect of adipose-derived mesenchymal stem and regenerative cells on lameness in dogs with chronicosteoarthritis of the coxofemoral joints: a randomized, double-blinded, multicenter, controlled trial. Vet Ther 2007;8:272-84.

[54] Black LL, Gaynor J, Adams C, Dhupa S, Sams AE, Taylor R, et al. Effect of intraarticular injection of autologous adipose-derived mesenchymal stem and regenerative cells on clinical signs of chronic osteoarthritis of the elbow joint in dogs. Vet Ther 2008;9:192-200.

[55] Fan CG, Zhang QJ, Zhou JR. Therapeutic potentials of mesenchymal stem cells derived from human umbilical cord. Stem Cell Rev 2011;7:195-207.

[56] Wang L, Tran I, Seshareddy K, Weiss ML, Detamore MS. A comparison of human bone marrow-derived mesenchymal stem cells and human umbilical cord-derived mesenchymal stromal cells for cartilage tissue engineering. Tissue Eng Part A 2009;15:2259-66.

[57] Fong CY, Subramanian A, Gauthaman K, Venugopal J, Biswas A, Ramakrishna S, et al. Human umbilical cord Wharton's jelly stem cells undergo enhanced chondrogenic differentiation when grown on nanofibrous scaffolds and in a sequential two-stage culture medium environment. Stem Cell Rev 2012;8:195-209.

[58] Wakitani S, Imoto K, Yamamoto T, Saito M, Murata N, Yoneda M. Human autologous culture expanded bone marrow mesenchymal cell transplantation for repair of cartilage defects in osteoarthritic knees. Osteoarthritis Cartilage 2002;10:199-206.

[59] Pak J. Regeneration of human bones in hip osteonecrosis and human cartilage in knee osteoarthritis with autologous adipose-tissue-derived stem cells: a case series. J Med Case Rep 2011;5:296.

[60] McInnes IB, Schett G. The pathogenesis of rheumatoid arthritis. N Engl J Med 2011;365:2205-19.

[61] Dudics V, Kunstár A, Kovács J, Lakatos T, Géher P, Gömör B, et al. Chondrogenic potential of mesenchymal stem cells from patients with rheumatoid arthritis and osteoarthritis: measurements in a microculture system. Cells Tissues Organs 2009;189:307-16.

[62] Jones E, Churchman SM, English A, Buch MH, Horner EA, Burgoyne CH, et al. Mesenchymal stem cells in rheumatoid synovium: enumeration and functional assessment in relation to synovial inflammation level. Ann Rheum Dis 2010;69:450-7.

[63] Marinova-Mutafchieva L, Williams RO, Funa K, Maini RN, Zvaifler NJ. Inflammation is preceded by tumor necrosis factor-dependent infiltration of mesenchymal cells in experimental arthritis. Arthritis Rheum 2002;46:507-13.

[64] Li X, Makarov SS. An essential role of NF-kappaB in the "tumor-like" phenotype of arthritic synoviocytes. Proc Natl Acad Sci USA 2006;103:17432-7.

[65] Djouad F, Fritz V, Apparailly F, Louis-Plence P, Bony C, Sany J, et al. Reversal of the immunosuppressive properties of mesenchymal stem cells by tumor necrosis factor alpha in collagen-induced arthritis. Arthritis Rheum 2005;52: 1595-603.

[66] Augello A, Tasso R, Negrini SM, Cancedda R, Pennesi G. Cell therapy using allogeneic bone marrow mesenchymal stem cells prevents tissue damage in collagen-induced arthritis. Arthritis Rheum 2007;56:1175-86.

[67] González MA, Gonzalez-Rey E, Rico L, Büscher D, Delgado M. Treatment of experimental arthritis by inducing immune tolerance with human adipose-derived mesenchymal stem cells. Arthritis Rheum 2009;60: 1006-19.

[68] Yañez R, Lamana ML, García-Castro J, Colmenero I, Ramírez M, Bueren JA. Adipose tissue-derived mesenchymal stem cells have in vivo immunosuppressive properties applicable for the control of the graft-versus-host disease. Stem Cells 2006;24:2582-91.

[69] Chen B, Hu J, Liao L, Sun Z, Han Q, Song Z, et al. Flk-1+ mesenchymal stem cells aggravate collagen-induced arthritis by up-regulating interleukin-6. Clin Exp Immunol 2010;159:292-302.

[70] Schurgers E, Kelchtermans H, Mitera T, Geboes L, Matthys P. Discrepancy between the in vitro and in vivo effects of murine mesenchymal stem cells on T-cell proliferation and collagen-induced arthritis. Arthritis Res Ther 2010;12:R31.

[71] Gonzalez-Rey E, Gonzalez MA, Varela N, O’Valle F, Hernandez-Cortes P, Rico L, et al. Human adipose-derived 


\section{P. Cipriani et al.}

mesenchymal stem cells reduce inflammatory and $\mathrm{T}$ cell responses and induce regulatory $\mathrm{T}$ cells in vitro in rheumatoid arthritis. Ann Rheum Dis 2010;69:241-8.

[72] Park MJ, Park HS, Cho ML, Oh HJ, Cho YG, Min SY, et al. Transforming growth factor $\beta$-transduced mesenchymal stem cells ameliorate experimental autoimmune arthritis through reciprocal regulation of Treg/Th17 cells and osteoclastogenesis. Arthritis Rheum 2011;63:1668-80.

[73] Liu Y, Mu R, Wang S, Long L, Liu X, Li R, et al. Therapeutic potential of human umbilical cord mesenchymal stem cells in the treatment of rheumatoid arthritis. Arthritis Res Ther 2010;12:R210.

[74] El-Jawhari JJ, El-Sherbiny YM, Jones EA, McGonagle D. Mesenchymal stem cells, autoimmunity and rheumatoid arthritis. QJM 2014;107:505-14.

[75] Tokano Y, Morimoto S, Amano H, Kawanishi T, Yano T, Tomyo $\mathrm{M}$, et al. The relationship between initial clinical manifestation and long-term prognosis of patients with systemic lupus erythematosus. Mod Rheumatol 2005;15: $275-82$.

[76] Cervera R, Khamashta MA, Font J, Sebastiani GD, Gil A, Lavilla $P$, et al. Morbidity and mortality in systemic lupus erythematosus during a 5-year period. A multicenter prospective study of 1,000 patients. European Working Party on Systemic Lupus Erythematosus. Medicine (Baltimore) 1999; 78:167-75.

[77] Ruiz-Irastorza G, Olivares N, Ruiz-Arruza I, MartinezBerriotxoa A, Egurbide MV, Aguirre C. Predictors of major infections in systemic lupus erythematosus. Arthritis Res Ther 2009;11:R109.

[78] Bernatsky S, Boivin JF, Joseph L, Manzi S, Ginzler E, Gladman DD, et al. Mortality in systemic lupus erythematosus. Arthritis Rheum 2006;54:2550-7.

[79] Sui W, Hou X, Che W, Chen J, Ou M, Xue W, et al. Hematopoietic and mesenchymal stem cell transplantation for severe and refractory systemic lupus erythematosus. Clin Immunol 2013;148:186-97.

[80] Sun LY, Zhang HY, Feng XB, Hou YY, Lu LW, Fan LM. Abnormality of bone marrow-derived mesenchymal stem cells in patients with systemic lupus erythematosus. Lupus $2007 ; 16: 121-8$

[81] Tang Y, Ma X, Zhang H, Gu Z, Hou Y, Gilkeson GS, et al. Gene expression profile reveals abnormalities of multiple signaling pathways in mesenchymal stem cell derived from patients with systemic lupus erythematosus. Clin Dev Immunol 2012;2012:826182.

[82] Gu Z, Cao X, Jiang J, Li L, Da Z, Liu H, et al. Upregulation of p16INK4A promotes cellular senescence of bone marrow-derived mesenchymal stem cells from systemic lupus erythematosus patients. Cell Signal 2012;24: 2307-14.

[83] Nie Y, Lau C, Lie A, Chan G, Mok M. Defective phenotype of mesenchymal stem cells in patients with systemic lupus erythematosus. Lupus 2010;19:850-9.

[84] Papadaki HA, Boumpas DT, Gibson FM, Jayne DR, Axford JS, Gordon-Smith EC, et al. Increased apoptosis of bone marrow CD34(+) cells and impaired function of bone marrow stromal cells in patients with systemic lupus erythematosus. Br J Haematol 2001;115:167-74.

[85] Heo JY, Jing K, Song KS, Seo KS, Park JH, Kim JS, et al. Downregulation of APE1/Ref-1 is involved in the senescence of mesenchymal stem cells. Stem Cells 2009;27: $1455-62$.

[86] Ebert R, Ulmer M, Zeck S, Meissner-Weigl J, Schneider D, Stopper H, et al. Selenium supplementation restores the antioxidative capacity and prevents cell damage in bone marrow stromal cells in vitro. Stem Cells 2006;24:1226-35.
[87] Maeda K, Malykhin A, Teague-Weber BN, Sun XH, Farris AD, Coggeshall KM. Interleukin-6 aborts lymphopoiesis and elevates production of myeloid cells in systemic lupus erythematosus-prone B6.Sle1.Yaa animals. Blood 2009; 113:4534-40.

[88] Essers MA, Offner S, Blanco-Bose WE, Waibler Z, Kalinke U, Duchosal MA, et al. IFNalpha activates dormant haematopoietic stem cells in vivo. Nature 2009; 458:904-8.

[89] Kang YJ, Yang SJ, Park G, Cho B, Min CK, Kim TY, et al. A novel function of interleukin-10 promoting self-renewal of hematopoietic stem cells. Stem Cells 2007;25:1814-22.

[90] Pronk CJ, Veiby OP, Bryder D, Jacobsen SE. Tumor necrosis factor restricts hematopoietic stem cell activity in mice: involvement of two distinct receptors. J Exp Med 2011;208:1563-70.

[91] Zhou K, Zhang H, Jin O, Feng X, Yao G, Hou Y, et al. Transplantation of human bone marrow mesenchymal stem cell ameliorates the autoimmune pathogenesis in MRL/lpr mice. Cell Mol Immunol 2008;5:417-24.

[92] Sun L, Akiyama K, Zhang H, Yamaza T, Hou Y, Zhao S, et al. Mesenchymal stem cell transplantation reverses multiorgan dysfunction in systemic lupus erythematosus mice and humans. Stem Cells 2009;27:1421-32.

[93] Choi EW, Shin IS, Park SY, Park JH, Kim JS, Yoon EJ, et al. Reversal of serologic, immunologic, and histologic dysfunction in mice with systemic lupus erythematosus by long-term serial adipose tissue-derived mesenchymal stem cell transplantation. Arthritis Rheum 2012;64:243-53.

[94] Gu F, Molano I, Ruiz P, Sun L, Gilkeson GS. Differential effect of allogeneic versus syngeneic mesenchymal stem cell transplantation in MRL/lpr and (NZB/NZW)F1 mice. Clin Immunol 2012;145:142-52.

[95] Wang D, Zhang H, Liang J, Li X, Feng X, Wang H, et al. Allogeneic mesenchymal stem cell transplantation in severe and refractory systemic lupus erythematosus: 4 years experience. Cell Transplant 2013;22:2267-77.

[96] Carrion F, Nova E, Ruiz C, Diaz F, Inostroza C, Rojo D, et al. Autologous mesenchymal stem cell treatment increased T regulatory cells with no effect on disease activity in two systemic lupus erythematosus patients. Lupus 2010; 19:317-22.

[97] Matucci-Cerinic M, Kahaleh B, Wigley FM. Review: evidence that systemic sclerosis is a vascular disease. Arthritis Rheum 2013;65:1953-62.

[98] Larghero J, Farge D, Braccini A, Lecourt S, Scherberich A, Foïs E, et al. Phenotypical and functional characteristics of in vitro expanded bone marrow mesenchymal stem cells from patients with systemic sclerosis. Ann Rheum Dis 2008; $67: 443-9$.

[99] Cipriani P, Guiducci S, Miniati I, Cinelli M, Urbani S, Marrelli A, et al. Impairment of endothelial cell differentiation from bone marrow-derived mesenchymal stem cells: new insight into the pathogenesis of systemic sclerosis. Arthritis Rheum 2007;56:1994-2004.

[100] Del Papa N, Quirici N, Soligo D, Scavullo C, Cortiana M, Borsotti C, et al. Bone marrow endothelial progenitors are defective in systemic sclerosis. Arthritis Rheum 2006;54: 2605-15.

[101] Cipriani P, Marrelli A, Benedetto PD, Liakouli V, Carubbi F, Ruscitti P, et al. Scleroderma Mesenchymal Stem Cells display a different phenotype from healthy controls; implications for regenerative medicine. Angiogenesis 2013;16:595-607.

[102] Guiducci S, Manetti M, Romano E, Mazzanti B, Ceccarelli C, Dal Pozzo S, et al. Bone marrow-derived mesenchymal stem cells from early diffuse systemic 
sclerosis exhibit a paracrine machinery and stimulate angiogenesis in vitro. Ann Rheum Dis 2011;70:2011-21.

[103] Cipriani P, Di Benedetto P, Liakouli V, Del Papa B, Di Padova M, Di Ianni $M$, et al. Mesenchymal stem cells (MSCs) from scleroderma patients (SSc) preserve their immunomodulatory properties although senescent and normally induce $\mathrm{T}$ regulatory cells (Tregs) with a functional phenotype: implications for cellular-based therapy. Clin Exp Immunol 2013;173:195-206.

[104] Christopeit M, Schendel M, Föll J, Müller LP, Keysser G, Behre G. Marked improvement of severe progressive systemic sclerosis after transplantation of mesenchymal stem cells from an allogeneic haploidentical-related donor mediated by ligation of CD137L. Leukemia 2008;22: 1062-4.

[105] Guiducci S, Porta F, Saccardi R, Guidi S, IbbaManneschi L, Manetti M, et al. Autologous mesenchymal stem cells foster revascularization of ischemic limbs in systemic sclerosis: a case report. Ann Intern Med 2010;153: $650-4$.

[106] Keyszer G, Christopeit M, Fick S, Schendel M, Taute BM, Behre $G$, et al. Treatment of severe progressive systemic sclerosis with transplantation of mesenchymal stromal cells from allogeneic related donors: report of five cases. Arthritis Rheum 2011;63:2540-2.

[107] Scuderi N, Ceccarelli S, Onesti MG, Fioramonti P, Guidi C, Romano F, et al. Human adipose-derived stromal cells for cell-based therapies in the treatment of systemic sclerosis. Cell Transplant 2013;22:779-95.

[108] Naraghi K, van Laar JM. Update on stem cell transplantation for systemic sclerosis: recent trial results. Curr Rheumatol Rep 2013;15:326.

[109] Byers PH, Wallis GA, Willing MC. Osteogenesis imperfecta: translation of mutation to phenotype. J Med Genet 1991;28:433-42.

[110] Cabral WA, Marini JC. High proportion of mutant osteoblasts is compatible with normal skeletal function in mosaic carriers of osteogenesis imperfecta. Am J Hum Genet 2004; $74: 752-60$.

[111] Pereira RF, O'Hara MD, Laptev AV, Halford KW, Pollard MD, Class R, et al. Marrow stromal cells as a source of progenitor cells for nonhematopoietic tissues in transgenic mice with a phenotype of osteogenesis imperfecta. Proc Natl Acad Sci USA 1998;95:1142-7.

[112] Guillot PV, Abass O, Bassett JH, Shefelbine SJ, BouGharios G, Chan J, et al. Intrauterine transplantation of human fetal mesenchymal stem cells from first-trimester blood repairs bone and reduces fractures in osteogenesis imperfecta mice. Blood 2008;111:1717-25.

[113] Caplan AI. Osteogenesis imperfecta, rehabilitation medicine, fundamental research and mesenchymal stem cells. Connect Tissue Res 1995;31:S9-14.

[114] Horwitz EM, Prockop DJ, Fitzpatrick LA, Koo WW, Gordon PL, Neel M, et al. Transplantability and therapeutic effects of bone marrow-derived mesenchymal cells in children with osteogenesis imperfecta. Nat Med 1999;5: 309-13.

[115] Horwitz EM, Gordon PL, Koo WK, Marx JC, Neel MD, McNall RY, et al. Isolated allogeneic bone marrow-derived mesenchymal cells engraft and stimulate growth in children with osteogenesis imperfecta: Implications for cell therapy of bone. Proc Natl Acad Sci USA 2002;99:8932-7.

[116] Le Blanc K, Götherström C, Ringdén O, Hassan M, McMahon R, Horwitz E, et al. Fetal mesenchymal stemcell engraftment in bone after in utero transplantation in a patient with severe osteogenesis imperfecta. Transplantation 2005;79:1607-14.
Mesenchymal stromal cells and rheumatic diseases

[117] Millington-Ward S, McMahon HP, Allen D, Tuohy G, Kiang AS, Palfi A, et al. RNAi of COL1A1 in mesenchymal progenitor cells. Eur J Hum Genet 2004;12:864-6.

[118] Amanatullah DF, Strauss EJ, Di Cesare PE. Current management options for osteonecrosis of the femoral head: part 1, diagnosis and nonoperative management. Am J Orthop (Belle Mead NJ) 2011;40:E186-92.

[119] Amanatullah DF, Strauss EJ, Di Cesare PE. Current management options for osteonecrosis of the femoral head: part II, operative management. Am J Orthop (Belle Mead NJ) 2011;40:E216-25.

[120] Matsuya H, Kushida T, Asada T, Umeda M, Wada T, Iida H. Regenerative effects of transplanting autologous mesenchymal stem cells on corticosteroid-induced osteonecrosis in rabbits. Mod Rheumatol 2008;18:132-9.

[121] Yan Z, Hang D, Guo C, Chen Z. Fate of mesenchymal stem cells transplanted to osteonecrosis of femoral head. J Orthop Res 2009;27:442-6.

[122] Peng J, Wen C, Wang A, Wang Y, Xu W, Zhao B, et al. Micro-CT-based bone ceramic scaffolding and its performance after seeding with mesenchymal stem cells for repair of load-bearing bone defect in canine femoral head. J Biomed Mater Res B Appl Biomater 2011;96:316-25.

[123] Feitosa ML, Fadel L, Beltrão-Braga PC, Wenceslau CV, Kerkis I, Kerkis A, et al. Successful transplant of mesenchymal stem cells in induced osteonecrosis of the ovine femoral head: preliminary results. Acta Cir Bras 2010;25: 416-22.

[124] Noël D, Djouad F, Jorgense C. Regenerative medicine through mesenchymal stem cells for bone and cartilage repair. Curr Opin Investig Drugs 2002;3:1000-4.

[125] Kuo TK, Ho JH, Lee OK. Mesenchymal stem cell therapy for nonmusculoskeletal diseases: emerging applications. Cell Transplant 2009;18:1013-28.

[126] Wen Q, Zhou L, Zhou C, Zhou M, Luo W, Ma L. Change in hepatocyte growth factor concentration promote mesenchymal stem cell-mediated osteogenic regeneration. J Cell Mol Med 2012;16:1260-73.

[127] Tang TT, Lu B, Yue B, Xie XH, Xie YZ, Dai KR, et al. Treatment of osteonecrosis of the femoral head with hBMP-2-gene-modified tissue-engineered bone in goats. J Bone Joint Surg Br 2007;89:127-9.

[128] Chan TW, Dalinka MK, Steinberg ME, Kressel HY. MRI appearance of femoral head osteonecrosis following core decompression and bone grafting. Skeletal Radiol 1991;20: 103-7.

[129] Gangji V, Hauzeur JP, Matos C, De Maertelaer V, Toungouz M, Lambermont M. Treatment of osteonecrosis of the femoral head with implantation of autologous bonemarrow cells. A pilot study. J Bone Joint Surg Am 2004; 86-A:1153-60.

[130] Wang BL, Sun W, Shi ZC, Zhang NF, Yue DB, Guo WS, et al. Treatment of nontraumatic osteonecrosis of the femoral head with the implantation of core decompression and concentrated autologous bone marrow containing mononuclear cells. Arch Orthop Trauma Surg 2010;130:859-65.

[131] Gangji V, De Maertelaer V, Hauzeur JP. Autologous bone marrow cell implantation in the treatment of non-traumatic osteonecrosis of the femoral head: Five year follow-up of a prospective controlled study. Bone 2011;49:1005-9.

[132] Zhao D, Cui D, Wang B, Tian F, Guo L, Yang L, et al. Treatment of early stage osteonecrosis of the femoral head with autologous implantation of bone marrow-derived and cultured mesenchymal stem cells. Bone 2012;50:325-30.

[133] Pak J. Autologous adipose tissue-derived stem cells induce persistent bone-like tissue in osteonecrotic femoral heads. Pain Physician 2012;15:75-85. 


\section{P. Cipriani et al.}

[134] Veronesi F, Torricelli P, Borsari V, Tschon M, Rimondini L, Fini M. Mesenchymal stem cells in the aging and osteoporotic population. Crit Rev Eukaryot Gene Expr 2011;21:363-77.

[135] Dalle Carbonare L, Valenti MT, Zanatta M, Donatelli L, Lo Cascio V. Circulating mesenchymal stem cells with abnormal osteogenic differentiation in patients with osteoporosis. Arthritis Rheum 2009;60:3356-65.

[136] Rosen CJ, Ackert-Bicknell C, Rodriguez JP, Pino AM. Marrow fat and the bone microenvironment: developmental, functional and pathological implications. Crit Rev Eukaryot Gene Expr 2009;19:109-24.

[137] Stenderup K, Justesen J, Eriksen EF, Rattan SIS, Kassem M. Number and proliferative capacity of osteogenic stem cells are maintained during aging and patients with osteoporosis. J Bone Miner Res 2001;16:1120-9.

[138] Astudillo P, Rios S, Pastenes L, Pino AM, Rodriguez JP. Increased adipogenesis of osteoporotic humanmesenchymal stem cells (MSCs) is characterized by impaired leptin action. J Cell Biochem 2008;103:1054-65.

[139] Bruder SP, Fink DJ, Caplan AI. Mesenchymal stem cells in bone development, bone repair, and skeletal regeneration therapy. J Cell Biochem 1994;56:283-94.

[140] Wang Z, Goh J, De Das S, Ge Z, Ouyang H, Chong JS, et al. EH Efficacy of bone marrow-derived stem cells in strengthening osteoporotic bone in a rabbit model. Tissue Eng 2006;12:1753-61.

[141] Ocarino Nde M, Boeloni JN, Jorgetti V, Gomes DA, Goes AM, Serakides R. Intra-bone marrow injection of mesenchymal stem cells improves the femur bone mass of osteoporotic female rats. Connect Tissue Res 2010;51:426-33.
[142] Nuttall ME, Patton AJ, Olivera DJ, Nadeau DP, Gowen M. Human trabecular bone cells are able to express both osteoblastic and adipocytic phenotype: implications for osteopenic disorders. J Bone Miner Res 1998; 13:371-82.

[143] Kanakaris NK, Petsatodis G, Tagil M, Giannoudis PV. Is there a role for bone morphogenetic proteins in osteoporotic fractures? Injury 2009;40(Suppl 3):S21-6.

[144] Kim D, Cho SW, Her SJ, Yang JY, Kim SW, Kim SY, et al. Retrovirus-mediated gene transfer of receptor activator of nuclear factor-kappaB-Fc prevents bone loss in ovariectomized mice. Stem Cells 2006;24:1798-805.

[145] Lien CY, Chih-Yuan Ho K, Lee OK, Blunn GW, Su Y. Restoration of bone mass and strength in glucocorticoidtreated mice by systemic transplantation of CXCR4 and cbfa-1 coexpressing mesenchymal stem cells. J Bone Miner Res 2009;24:837-48.

[146] Chen HT, Lee MJ, Chen CH, Chuang SC, Chang LF, Ho ML, et al. Proliferation and differentiation potential of human adipose-derived mesenchymal stem cells isolated from elderly patients with osteoporotic fractures. J Cell Mol Med 2012;16:582-93.

[147] Maumus M, Guérit D, Toupet K, Jorgensen C, Noël D. Mesenchymal stem cell-based therapies in regenerative medicine: applications in rheumatology. Stem Cell Res Ther 2011;2:14.

[148] MacFarlane RJ, Graham SM, Davies PS, Korres N, Tsouchnica $\mathrm{H}$, Heliotis $\mathrm{M}$, et al. Anti-inflammatory role and immunomodulation of mesenchymal stem cells in systemic joint diseases: potential for treatment. Expert Opin Ther Targets 2013;17:243-54. 